\title{
IRREGULAR MIGRATION AS AN OBJECT OF RESEARCH IN THE CONTEXT OF FINDING WAYS TO IMPROVE THE EFFECTIVENESS OF ORGANIZING COUNTERACTION IN THE AREA OF RESPONSIBILITY OF CHOP BORDER GUARD DETACHMENT OUTSIDE BORDER CROSSING POINTS
}

\section{Volodymyr Kyrylenko}

\section{INTRODUCTION}

Protection of the state border ${ }^{1}$ by Chop Border Guard Detachment is performed at the border sector with the following types of area: mountainous terrain, which is characterized by an acute change of weather during the day, mountain collapses, avalanches, landslides; with water obstacles; difficult to access areas; sparsely populated; with a poorly developed road network; carrying out seasonal work in the border zone and controlled border areas. The conditions inherent in the area of responsibility of Chop Border Guard Detachment can both facilitate and hinder the actions of offenders, and the actions of the forces of the Border Guard Service Divisions in performing tasks for the protection of the state border, which affects the effectiveness of the tasks of operational and service activity by Border Guard units.

The existing scientific and methodological apparatus of operationaltactical calculations for the organization of operational-service activity (OSA) is developed for the conditions of service for specific areas of the state border (wooded area, forest, river, etc.) and, in general, for the organization's operational activities on the sector of a typical border guard detachment. That means it does not take into account the specifics of a particular border patrol, only internal and external threats and risks (in general, illegal activities are associated with illegal migration, smuggling, at checkpoints and outside them) that are inherent in this region of Ukraine. This reveals the need to find real ways to improve the effectiveness of the organization of combating illegal migration in the area of responsibility of Chop Border Guard Detachment outside the checkpoints.

1 Tematychnyy analiz ryzykiv: vyznachennya zahroz ta ryzykiv na dilyantsi zahonu $\mathrm{z}$ metoyu vyznachennya zavdan' pidporyadkovanym pidrozdilam na okhoronu derzhavnoho kordonu v 2019 rotsi (2018) [Thematic Risk Analysis: Identifying Threats and Risks at the Detachment Area to Identify Tasks for Subordinate Border Protection Units in 2019]. Chop, p. 26. (in Ukraine) 
Analysis of recent research and publications. A large number of scientific papers (for example ${ }^{2,3,4,5,6,7,8}$ ) have been devoted to the study of evaluating the effectiveness of performing the tasks assigned to border units for OSA during the defined period However, the issues of illegal migration as an object of research in the context of finding ways to improve the effectiveness of the organization of combating illegal migration in the area of responsibility of Chop Border Detachment outside the checkpoints were not considered.

${ }^{2}$ Stratehiya intehrovanoho upravlinnya kordonamy na period do 2025 roku [Elektronuj resurs] Rozporyadzhennya Kabinetu Ministriv Ukrayinu vid 24 lypnya 2019 roku № 687-r. Rezhum dostupu: https://zakon.rada.gov.ua/laws/show/687-2019-\%D1\%80 (data zvernennya: 30.12.2019) [An integrated border management strategy for the period up to 2025: [Electronic Resource] Order of the Cabinet of Ministers of Ukraine No. 687-r as of July 24, 2019, available at: https://zakon.rada.gov.ua/laws/show/687-2019-\%D1\%80].

3 Pro Rishennya Rady natsionalnoyi bezpeky i oborony vid 06 travnya 2015 r. «Pro Stratehiyu natsionalnoyi bezpeky Ukrayiny». Ukaz Prezydenta Ukrayiny vid 06 travnya $2015 \mathrm{r}$. № 287/2015. [Elektronuy resurs] - Rezhy`m dostupu: http://zakon3.rada.gov.ua/laws/show/ n0008525-15 [On the Decision of the National Security and Defense Council as of May 06, 2015 « About the National Security Strategy of Ukraine» Decree of the President of Ukraine as of May 06, 2015, available at: http://zakon3.rada.gov.ua/laws/show/n0008525-15.

4 Zakon Ukrayiny № 661-IV «Pro derzhavnu prukordonnu sluzhbu Ukrayinu» vid 3 kvitnya 2003 roku (Vidomosti Verxovnoyi Radu Ukrayinu, 2003, N 27, st. 2, 20). [Law No. 661-IV of Ukraine On the State Border Service of Ukraine as of April 3, 2003 (The Official Bulletin of the Verkhovna Rada of Ukraine (OBVR)), 2003, 27, Art. 208)]. [in Ukrainian]

5 Mejko O. V. (2014) Metoduka vuznachennya racionalnogo varianta zastosuvannya mobilnux grup okremogo viddilu prukordonnoyi sluzhbu tupy "S" pid chas uskladnennya obstanovku na dilyankax derzhavnogo kordonu [Methods of determining the rational variant of the use of Type $\mathrm{C}$ mobile teams of a separate department of the border service during the aggravation of the situation at the state border sections] Zbirnyk naukovykh prats, Kharkiv : $K N A F U$, No. 4 (41), pp. 153-156. [in Ukrainian]

6 Farion O. B. (2009) Metoduka ocinku efektuvnosti sustemu informacijnogo zabezpechennya viddilu prukordonnoyi sluzhbu tupy «B» [Methods of evaluation of the effectiveness of the system of information support of the Type B department of the border service] Zbirnyk naukovykh prats Natsionalnoi akademii Derzhavnoi prykordonnoi sluzhby Ukrainy im. B. Khmelnytskoho, Khmelnytskyi : NASBSU, no. 49, pp. 97-115. [in Ukrainian]

7 Kovalev D. V. (2017) Algorutm metoduku vuznachennya racionalnogo varianta organizaciyi operatuvno-sluzhbovoyi diyalnosti viddiliv prukordonnoyi sluzhbu tupy "A" $\mathrm{v}$ kontrolnux punktax vyizdu/vyjizdu [Algorithm of methodology of determination of rational variant of organization of operatively-official activity of departments of frontier service as «A» in the markpoints of entrance/of departure]. Zbirnyk naukovykh prats Natsionalnoi akademii Derzhavnoi prykordonnoi sluzhby Ukrainy im. B. Khmelnytskoho, Khmelnytskyi : NASBSU, no. 2(72), pp. 116-125. [in Ukrainian]

${ }^{8}$ Shinkaruk O. M., Mosov S. P., Kirilenko V. A. (2018) Prykordonna bezpeka Ukrayiny: stanovlennya, suchasnyy stan, problemy i perspektyvy: monohrafiya [Border security of Ukraine: formation, current state, problems and prospects: monograph]. Khmelnytsky : $N A S B S U$, p. 187 p. [in Ukrainian] 
The purpose of the article is the reveal the notion of irregular migration and the specific tasks of OSA regarding its counteracting in the area of responsibility of Chop Border Guard Detachment and finding ways to improve it (counteract) efficiency.

\section{Types of encroachments on the integrity of the state border}

World processes in the era of globalization are significantly affected by such a complex socio-economic, legal and political phenomenon as migration - one of the most serious problems of our time, the flows of which have reached such proportions that the governments of different countries cannot ignore this phenomenon ${ }^{9,10,11}$.

According to the analysis of scientific sources, despite certain differences, the concept of migration is defined as relocation, the movement of a population (an individual or groups of people within a country or from one country to another, which is aimed at acquiring resources in new territories and is associated with a temporary or permanent change of residence $^{12,13,14}$.

Types of migration depend on the criteria for its classification, namely:

ways - organized and unorganized;

degree of control - legal and illegal;

territorial characteristics - internal and external;

temporary characteristics - irreversible, temporary, seasonal, nomadic;

relationship to the host country, emigration, immigration, assimilated, transit.

According to the legal basis, migrants are divided into:

legal - who cross international borders legally;

semi legal - arrive legally and change their status);

illegal - cross the state border:

- outside checkpoints;

\footnotetext{
${ }^{9}$ Blazhivsky E. M. (2008) International migration is one of the biggest problems of modern Ukraine. Visn. prokuratu, no. 6. pp. 3-13. [in English]

${ }^{10}$ Rashitov L. R. (2016) Criminological characteristics of crimes in the sphere of illegal migration and their prevention. BULLETIN of the Kazan law Institute of the Ministry of internal Affairs of Russia, no. 1(23), pp. 124-28. (in English)

11 Malinovska O. A. (2018) Migration policy: global context and Ukrainian realities: monograph. Kiev : NISD, 472 p. (in English)

${ }^{12}$ Purygina O. G. (2007) International migration: studies. stipend. Kiev : VC «Academy», 312 p. (in English)

${ }^{13}$ Babiia V. M., Koretsky V. M. (1974) Law dictionary / edited by academics of VSSR Academy of Sciences. Kiev, 844 p. (in English)

${ }^{14}$ Gusarov S. M., Komzuk A. T., Salmanova A. Yu. (2016) Migration law of Ukraine : textbook. Kharkiv : advertising House, 296 p. (in English)
} 
- through checkpoints using forged (invalid) documents;

- through checkpoints with concealment in the design features of vehicles, in cargo, using other ways to avoid border control) ${ }^{1516}$.

Today there is no single approach to defining the concept of «irregular (illegal) migration» as opposed to the concept of «Illegal migrant».

According to paragraph 14, paragraph 1 of article 1 of the Law of Ukraine «On the legal status of foreigners and stateless persons», an illegal migrant is a foreigner or a stateless person who crossed the state border outside checkpoints or at checkpoints, but with the avoidance of border control and did not immediately apply for refugee status or asylum in Ukraine, as well as a foreigner or a stateless person who legally arrived in Ukraine, but after a certain period of stay lost their grounds for further stay and evade departure from Ukraine ${ }^{17}$.

The term «illegal migration» is a generally accepted concept for determining the movement of people across state borders in violation of legal norms. The terms «illegal migration «and» irregular migration» are used as synonyms. However, this term is most often used in official documents, while the concept of «illegal migration» is characteristic of scientific research and journalistic texts ${ }^{18}$.

In contrast to international law, the concept of «illegal» or «irregular» migration prevails in national laws and regulations of the EU, which reflects the priority of the state's interests. According to the definition of the International organization for migration, these terms are identified with the concept of unregulated migration. Recently, the terms «managed» and «unmanaged» migration are increasingly used in publicistic works, scientific research, and international speeches, but their definition is not given ${ }^{19}$.

Illegal (irregular) migration is illegal movement across the state border, that is, outside checkpoints or hiding from border and customs control, using false documents, a visa (or without a visa), independently or with the help of

${ }^{15}$ Kuzmenko O. V. (2000) Administrative and legal counteraction to illegal migration in Ukraine: dis. ... Cand. Law. Sciences. Kiev, 196 p. (in Ukrainian)

${ }^{16}$ Mosiondz S. O. (2005) Administrative and legal bases of the state migration policy in Ukraine. Kyiev : Master of the twenty-first century, 206 p. (in Ukrainian)

${ }^{17}$ On the legal status of foreigners and stateless persons. Law of Ukraine No. 3773-VI of September 22, 2011 (Vidomosti Verkhovnoi Rady Ukrainy (VVR), 2012, No. 19-20, art. 179). Retrieved from: https://zakon.rada.gov.ua/laws/show/3773-17. (in Ukrainian)

${ }^{18}$ Binkovskyi O. A., Zalozh V. V., Dovgan V. I. (2016) Mechanisms for countering irregular migration in Ukraine. Eurasian Academic Research Journal, no. 2(02), pp. 14-22. (in English)

19 Shevchenko O. M. (2010) Udoskonalennja mekhanizmiv derzhavnogho upravlinnja mighracijnymy procesamy [Improving the mechanisms of state management of migration processes]. Donetsk. 2010. 25 p. (in Ukrainian) 
third parties, as well as residence on the territory of the country without the proper permission of the competent state authorities ${ }^{20,21}$.

We support the point of view of those scientists who believe that illegal migration is crossing the borders of a state for a purpose or in a manner that violates legislation, including international law ${ }^{22}$.

\section{Illegal migration as a type of organized crime that encroaches on the inviolability of the state border}

Chop border guard detachment of the Western Regional Directorate of the State Border Guard Service protects the state border within three controlled border areas (Velyky Bereznyi, Perechyn, Uzhgorod) with three EU States and a total length of $149.4 \mathrm{~km}$ : Poland $(30.9 \mathrm{~km})$, Slovakia $(97.85 \mathrm{~km})$ and Hungary $(20.65 \mathrm{~km})$.

Of these, the land sector is $132 \mathrm{~km} 600$ meters (mountain $83 \mathrm{~km}$ ), along the rivers- $16 \mathrm{~km} 800$ meters. The state border mostly (57\%) passes through mountainous, wooded, heavily rugged terrain. The main units of the state border protection are: 3 divisions of the border service, which includes 16 sections of border guard service of inspectors and the $\langle\mathrm{C} »$ type border service division. Current vulnerabilities of major and minor threats are presented in the table. 1 .

Table 1

\section{Current vulnerabilities of major and minor threats}

\begin{tabular}{|c|c|}
\hline № & Vulnerabilities \\
\hline \multicolumn{2}{|r|}{ I. Vulnerabilities of major threats } \\
\hline 1.1 & $\begin{array}{l}\text { Unstable socio-economic and political situation, local military conflicts and wars in } \\
\text { the countries that are the main sources of illegal migrants, which causes further } \\
\text { activity of the process of illegal migration from the countries of South-East Asia, } \\
\text { North and West Africa, the Middle East, the post-Soviet space, transit through } \\
\text { Ukraine to the EU member States }\end{array}$ \\
\hline 1.2 & Russian military aggression in Eastern Ukraine \\
\hline 1.3 & $\begin{array}{l}\text { Destabilization of the socio-economic and political situation in Ukraine } \\
\text { by pro-Russian forces }\end{array}$ \\
\hline 1.4 & $\begin{array}{l}\text { Significant difference in prices for tobacco products in Ukraine and neighboring } \\
\text { countries }\end{array}$ \\
\hline
\end{tabular}

${ }^{20}$ Zakharchenko M. (2014) Prychyny ta sutnistj javyshha nereghuljarnoji (neleghaljnoji) mighraciji [Reasons and essence of the phenomenon of irregular (illegal) migration]. Customs activity, pp. 262-267. (in Ukrainian)

${ }^{21}$ Mozol A. P. (2002) Kryminologhichni problemy neleghaljnoji mighraciji v Ukrajini [Criminological problems of illegal migration in Ukraine]. Kiev, 212 p. (in Ukrainian)

${ }^{22}$ Ognev T. E. (2017) Nereghuljarna mighracija: kryminaljne pravo ta kryminologhichni aspekty [Irregular migration: criminal law and criminological aspects]. Institute of state and law. V. M. Koretsky, 20 p. (in Ukrainian) 


\begin{tabular}{|c|c|}
\hline № & $\begin{array}{ll}\text { Vulnerabilities } \\
\end{array}$ \\
\hline 1.5 & $\begin{array}{l}\text { High financial income for the organization and implementation of illegal } \\
\text { transportation of persons across the state border of Ukraine to the countries } \\
\text { of the Schengen agreement }\end{array}$ \\
\hline 1.6 & $\begin{array}{l}\text { High unemployment rate in border areas, close family ties between residents } \\
\text { of the border area of Ukraine and neighboring countries }\end{array}$ \\
\hline 1.7 & $\begin{array}{l}\text { Difficult terrain in places where the state border passes, the presence } \\
\text { of mountainous, wooded areas, which limits the use of optoelectronic devices } \\
\text { in border protection and allows illegal migrants, illegal activity guides } \\
\text { to approach the state border covertly }\end{array}$ \\
\hline 1.8 & $\begin{array}{l}\text { Absence of criminal liability, significant fines for illegal crossing of the state } \\
\text { border, for smuggling, for violation of migration legislation and loyal attitude } \\
\text { of the courts in the direction of punishment for crimes under article } 332 \\
\text { of the criminal code of Ukraine }\end{array}$ \\
\hline 1.9 & Lack of an effective mechanism for deporting illegal migrants \\
\hline 1.10 & Low staffing of border protection units $(50-60 \%)$ \\
\hline 1.11 & $\begin{array}{l}\text { Rotation of the management of units, which does not allow to deal with the } \\
\text { situation and respond adequately to its changes, does not allow to effectively } \\
\text { manage the division }\end{array}$ \\
\hline 1.12 & $\begin{array}{l}\text { Corruption, involving or facilitating illegal activity on the state border } \\
\text { of the state security service of Ukraine }\end{array}$ \\
\hline 1.13 & $\begin{array}{l}\text { Corruption in migration and law enforcement agencies, which makes it impossible } \\
\text { to prevent illegal migrants and contraband goods from entering the border zone }\end{array}$ \\
\hline 1.14 & $\begin{array}{l}\text { Activity of national diasporas and communities on the territory of Ukraine } \\
\text { (Afghanistan, Pakistan, Somalia, Georgia, Armenia, etc.) that provide conditions } \\
\text { for illegal migration }\end{array}$ \\
\hline 1.15 & $\begin{array}{l}\text { Activity of transnational and cross-border criminal groups that specialize in } \\
\text { smuggling illegal migrants, human trafficking and smuggling of narcotic and } \\
\text { psychotropic substances, a stable and extensive support base among residents of the } \\
\text { border area }\end{array}$ \\
\hline 1.16 & $\begin{array}{l}\text { Continued improvement of border and immigration policies by EU governments, } \\
\text { strengthening of the EU external border protection system by border agencies of } \\
\text { neighboring countries, and increasing efforts to develop border infrastructure and } \\
\text { technical equipment for units }\end{array}$ \\
\hline 1.17 & $\begin{array}{l}\text { Lack of proper technical equipment of border units (vehicles, thermal imaging } \\
\text { systems and devices, radar for detecting MLA UAVs), insufficient engineering } \\
\text { arrangement of the border, especially along the Tisa river }\end{array}$ \\
\hline 1.18 & $\begin{array}{l}\text { Limitations of material and financial resources to perform the tasks } \\
\text { in securing the border }\end{array}$ \\
\hline 1.19 & $\begin{array}{l}\text { Insufficient equipment of certain parts of the boundary ( «Tisa», «Salovka», } \\
\text { «Palad - Komarivtsi») }\end{array}$ \\
\hline 1.20 & $\begin{array}{l}\text { Use by offenders of the latest thermal imaging, optical devices, and modern } \\
\text { unmanned aerial vehicles (drones) in order to expose the border security system }\end{array}$ \\
\hline 1.21 & $\begin{array}{l}\text { The use of aircraft for the illegal movement of goods and persons across the state } \\
\text { border (with the help of aircraft, offenders carry out the movement of illegal } \\
\text { migrants, cigarettes from the rear areas located outside the border controlled areas) }\end{array}$ \\
\hline \multicolumn{2}{|r|}{ II. Minor threat vulnerabilities } \\
\hline 2.1 & $\begin{array}{l}\text { Unstable socio-economic and political situation in Ukraine and its destabilization } \\
\text { by pro-Russian forces }\end{array}$ \\
\hline 2.2 & $\begin{array}{l}\text { Significant difference in prices for tobacco products in Ukraine and neighboring } \\
\text { countries }\end{array}$ \\
\hline
\end{tabular}




\begin{tabular}{|l|l|}
\hline \multicolumn{1}{|c|}{ № } & \multicolumn{1}{c|}{ Vulnerabilities } \\
\hline 2.3 & $\begin{array}{l}\text { High unemployment rate in border areas, close family ties between residents } \\
\text { of the border area of Ukraine and neighboring countries }\end{array}$ \\
\hline 2.4 & $\begin{array}{l}\text { Corruption, involving or facilitating illegal activity on the state border of the state } \\
\text { security service of Ukraine }\end{array}$ \\
\hline 2.5 & $\begin{array}{l}\text { No criminal liability, significant fines for smuggling, or violation } \\
\text { of customs legislation }\end{array}$ \\
\hline 2.6 & $\begin{array}{l}\text { The lack of proper technical equipping of border crossing points } \\
\text { (common database, inspection scanners) }\end{array}$ \\
\hline 2.7 & $\begin{array}{l}\text { Low staffing of border protection units, which causes a significant service load } \\
\text { on the staff, and as a result - a decrease in the efficiency of the service }\end{array}$ \\
\hline 2.8 & $\begin{array}{l}\text { Discrepancy in the capacity of checkpoints, which significantly reduces the } \\
\text { efficiency of passport and inspection work }\end{array}$ \\
\hline
\end{tabular}

The points listed in the table can be attributed to the sphere of influence: 1.1-1.4, 1.5, 1.6, 1.16, 2.1-2.3 and 2.8 - socio-political; 1.9, 1.13-1.15, 2.4, 2.5 law enforcement agencies (SSU, MIA, OPGU, etc.); 1.10-1.12, 2.6, 2.7 the managerial staff of the State Border Guard Service (their resolution requires some research); 1.7 - operational and tactical level of management of border units, elimination of this vulnerability depends on making adequate management decision to find scientifically sound ways and mechanisms of organization of counteraction to the mentioned criminal activity.

The ways of trafficking people across the state border are constantly changing under the influence of migration and other factors ${ }^{23}$.

In view of this, it is imperative to investigate ways of committing crimes that reveal the peculiarities of the activities of the diverse body of actors involved in its commission, which is inherent in organized criminal activity related to the illegal movement of illegal migrants across the state border.

Taking into account the peculiarities of criminal activity, which is connected with the illegal trafficking of persons across the state border, in our opinion, the way of transfer of persons across the state border is defined as an interdependent set of actions of persons whose activity is generally aimed at transferring persons across the state border of Ukraine violating the current legislation requirements, as well as persons who cross the state border of Ukraine ${ }^{24}$.

${ }^{23}$ Kapitanchuk L. Yu. (2009) Okremi pytannja rozsliduvannja porushenj derzhavnogho kordonu Ukrajiny za uchastju neleghaljnykh mighrantiv [Separate issues of investigation of violations of the state border of Ukraine with the participation of illegal migrants]. Universytetsjki naukovi zapysky, no. 1. pp. 306-312. (in Ukrainian)

${ }^{24}$ Kapitanchuk L. Yu. (2008) Sposib vchynennja zlochynu ta jogho osoblyvosti pry nezakonnomu perepravlenni osib cherez derzhavnyj kordon Ukrajiny [Sposib vchynennja zlochynu ta jogho osoblyvosti pry nezakonnomu perepravlenni osib cherez derzhavnyj kordon Ukrajiny]. Forum prava, no. 2, pp. 210-219. (in Ukrainian) 
The analysis of criminal activities related to the illicit movement of persons, including illegal migrants across the state border, shows that traffickers are constantly taking steps to improve existing methods and develop new ones in order to minimize the effectiveness of law enforcement.

The practice of combating illegal migration shows that irregular migrants travel to EU countries across the national border outside the border crossing points (from 3 to 8 people), both individually (using maps and GPS navigators), and accompanied by local border assistants or representatives of foreign diasporas.

Legalization of illegal migrants on the territory of Ukraine is carried out by: first, changes in the status of stay (receiving MIA records on employment, temporary residence or study), second, the extension of your stay, third, the use of the refugee status procedure ${ }^{25}$.

The analysis of the results of the operational service of the border unit in the period from June 2017 to May 2018 in comparison with the same previous period shows a slight decrease in the activity of illegal crossing of the state border by illegal migrants. The most active is the Slovak border area, where $91 \%$ of attempts to violate the state border and $9 \%$ at the border with Hungary and $1 \%$ at the border with Poland were stopped during the study period.

Analyzing the general trends of 2016-2018, we can notice the dynamics of illegal activity by periods of the year, which shows that the decline in activity is observed in January - March, which is primarily due to seasonal deterioration of weather conditions and $100 \%$ readmission of detained illegal migrants since November 2016.The peak periods in this type of illegal activity in the area of responsibility of the border detachment were: in 20162017 - May, August, in 2017-2018 - May, August - September.

The most active time of day was the time from $8 \mathrm{pm}$ to $8 \mathrm{am}$. The highest activity of attempts of illegal crossing on the state border by illegal migrants took place within the areas of responsibility of Uzhgorod BGD, Huta BGIS, Palad Komarivtsi BGIS, Novoselytsya and Stuzytsya BGIS.

The main way of getting migrant groups to Ukraine is on the border with the Russian Federation outside the border crossing points. Due to the warfare in the east of Ukraine, illegal elements began to make more active use of border areas within the north-eastern regions of Ukraine (Kharkiv, Sumy,

${ }^{25}$ Kapitanchuk L. Yu., Litvin Yu. I. (2015) Vplyv zminy potokiv neleghaljnoji mighraciji na formuvannja kryminalistychnoji kharakterystyky nezakonnogho perepravlennja osib cherez derzhavnyj kordon Ukrajiny [Influence of Changes in Illegal Migration Flows on Formation of Forensic Characteristics of Illegal Trafficking of Persons across the State Border of Ukraine]. Dosudove rozsliduvannja : aktualjni problemy ta shljakhy jikh vyrishennja : materialy postijno dijuchogho nauk. - prakt. seminaru. Pravo, no. 7. pp. 344. (in Ukrainian) 
and Chernihiv regions). As a rule, the transportation of illegal migrants was carried out from Moscow to the places of accumulation and formation of groups on the territory of Ukraine (Kyiv, Odessa) and further to the Transcarpathian region. In this case, as a rule, automobile transport means (cars, minibuses) were used for delivery to the border, and automobile transport means of improved cross-country performance for direct delivery to the state border.

A relatively new element of the tactics of illegal elements was the «temporary legalization» of foreigners on the territory of Ukraine upon their arrival through the established crossing points (mainly - the airports «Boryspil», «Zhuliany», «Odessa» [Dubai-Kiev connecting flights, «Istanbul - Odessa» and «Istanbul - Kiev»). In particular, short-term visas are issued to foreigners through representatives of travel companies at the airport, which give legal grounds for staying in Ukraine for a short time. Furthermore, illegal migrants are deprived of their documents and illegally trafficked by organizers of illegal activities on the western border.

The use of settlements in Perechyn, Chop, Velyka Berezny and Uzhgorod districts for the short-term detention of migrant groups before their direct cross-border transferring is the characteristic feature of the tactics of the criminal groups. The tasks of transportation, hiding of groups on the border and escorting them across the border were carried out by both persons from criminogenic environment and by single persons involved.

Transportation of groups of illegal migrants to the Transcarpathian region is carried out mainly from Kharkiv, Lviv, Kyiv and Odessa. Delivery of unorganized groups of illegal migrants by buses is carried out mainly by inter-oblast buses «Kyiv - Uzhgorod», «Lviv - Uzhgorod», «IvanoFrankivsk - Uzhgorod», «Chernivtsi - Uzhgorod», «Rakhiv - Uzhgorod».

Delivery of small groups of illegal migrants by railway can be carried out by trains by connection No 81 «Kyiv-Uzhgorod», No. 13 «Kyiv-Uzhgorod», No. 99 «Kyiv-Uzhgorod», No. 107 «Odessa-Uzhgorod», No. 601 «Lviv Solotvyno» and No. 829 "Lviv-Uzhgorod".

Regarding the tactics of unorganized groups of illegal migrants and small groups that are transported with the help of assistants, it is worth noting that, upon arrival in the Transcarpathian region, illegal migrants are settled in private apartments (houses). After some time, they are usually escorted by two or three people (guides) across the state border by car or on foot. As a rule, organizers of the illegal transfer of persons involve 1 well-oriented local resident and 1-2 conductors from the settlements far from the border area. Small groups of illegal migrants (in most cases up to 5 people) are escorted to the border barrier or to the state border line.

Later on, migrants independently move to the nearest settlement on the adjacent territory. Traffic routes to the border are chosen in such a way as to 
minimize the occurrence of locals on the route, as well as to provide maximum concealing with the help of terrain features. As a rule, observers move forward in a small distance in front of a group of migrants to monitor the possible appearance of border guard patrol units.

In the case of detention in an adjacent territory, migrants use the socalled "treatment of the refugee status" tactics in order to avoid readmission in the territory of Ukraine. During the preparation of the procedural documents by the representatives of the law enforcement agencies, the migrants indicate deliberately false constituent data, use the "legends" that have been brought to them (emphasis is placed on the fact that they are minors, constantly repudiation of actual staying in Ukraine, etc.).

In total, at the detachment sector 417 irregular migrants were detained during June, 2017 and May, 2018, in 90 cases. [1] (a decrease of 1.7 times by the number of detained persons [248 persons were detained during the same period in 93 cases]).

Including the SBGS units: in 47 cases, $52 \%$ of the total cases in the period from 06.2017 to $05.2018,161$ irregular migrants, $39 \%$ of the total number of detainees (an increase of $5 \%$ on cases and $25 \%$ on the number detainees [during the same period in the past, in 45 cases detained 120 persons]); Border Guard Units of Adjacent Country: during 06.2016 and 05.2017 , in 43 cases, $48 \%$ of the total number of cases, 258 irregular migrants, $61 \%$ of the total number of detainees $(5 \%$ reduction in cases and 2 times the number of detainees [during the same period in the past, in 48 cases detained 128 persons]).

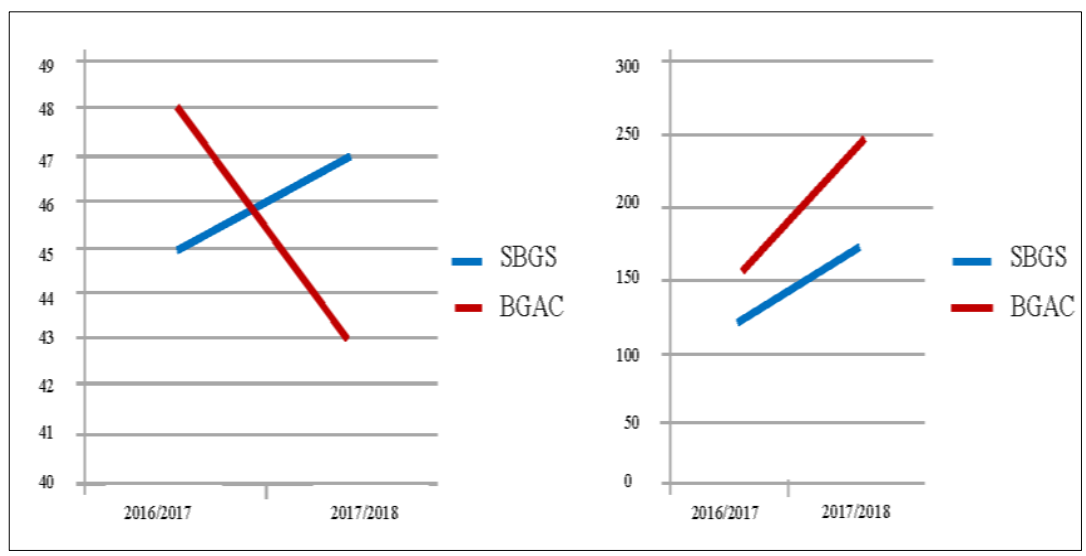

Fig. 1. Dynamics of detention of irregular migrants 
During this period, 417 people were detained in 90 cases, including:

Ukrainian and Slovakian border sector: in 77 cases, $85 \%$ of the total number during the report period, 365 irregular migrants, $87 \%$ of the total detainees during the reported period.

Ukrainian and Hungarian border sector: in 7 cases, $8 \%$ of the total number 24 irregular migrants during the report period, $6 \%$ of the total detainees during the reported period;

Ukrainian and Polish border sector: in 6 cases, 7\% of the total number 28 irregular migrants during the report period, $7 \%$ of the total number of detainees during the reported period;

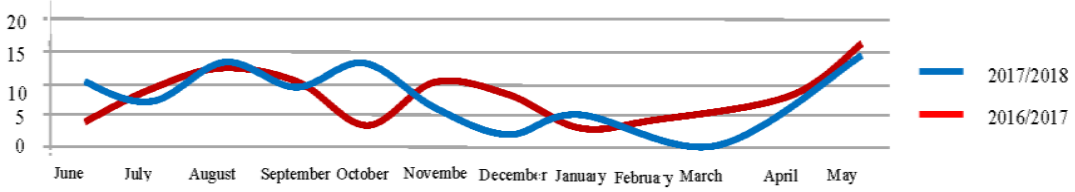

Fig. 2. Cases

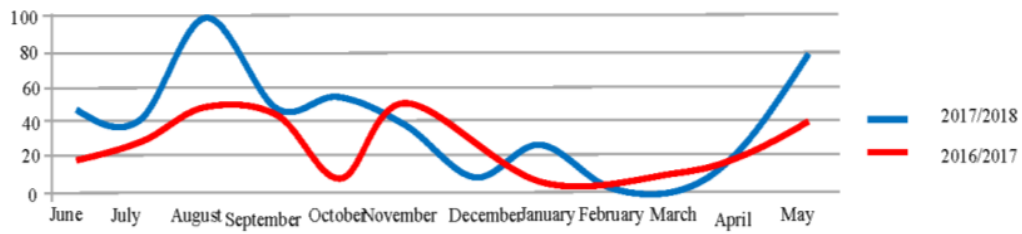

Fig. 3. Detained persons

The analysis of the results of the operational and service activity of the units of the state border protection indicates that the stable threat of illegal activity production with the use of new tactics and the latest technical means, and the OSA processes outside the checkpoints have a previously unpredictable (accidental) nature.

In 2018 - 2019, the border detail revealed «photo traps» that were disguised installed along the route of the border patrols. When border details appered in the range of the device in real time, the photo from the device was sent to a pre-programmed mobile phone number of the irregular element. In this way, the situation was monitored by illegal elements and the system of state border guard protection was opened. 
Illegal elements have been actively used by unmanned aerial vehicles (UAVs) to track the movement of border details, as well as to smuggle small batches of cigarettes.

For small aerial vehicle (SAV) tactics, landing strips were used at various locations outside the boundary strip in the rear areas of the controlled border guard region, border guard area or other areas of the country. On the adjacent territory the cargo (up to 10 packs of cigarettes) is dumped into the designated place without landing the aerial vehicle with the subsequent return to the territory of Ukraine. As a rule, flights are made at night in order to complicate the possibility of visual observation and a low altitude to avoid their detection by technical means of aerial defense of the Ministry of Defense of Ukraine. Delivery of SAV was carried out disassembled in cargo minibuses. Subsequently, they were quickly assembled, loaded with tobacco goods. The flights were made at night by GPS navigators by professional pilots. On the adjacent territory SAVs could not land, throwing cigarettes on the go.

Returning were made in a different direction to a predefined platform. When SAV lands, it knocked down and loaded in vehicles. The tactics of the action are characterized by greater mobility of the use of technical means, such as night vision equipment, GPS navigators, mobile phones, etc.

In March 2018, using the AN-2 aircraft, the illegal movement of a group of 11 irregular migrants from the backland of Ukraine to Hungary was made, so the possibility of using SAVs for the illegal movement of irregular migrants across the state border is not excluded.

During June 2016 - May 2018, 40 airspace violations were reported, 3 SAVs were detained.

During June 2017 - May 2018, 23 airspace violations were reported. 3 UAVs were detained.

Based on the analysis of SVA violations and UAVs during 2016-2018, it can be stated that the most active areas of possible engagement of SVAs are: Salovka, Tisa, Palad Komarivtsi BG Divisions. Period from March to October should be considered like a minatory period.

The most active areas of possible engagement of UAVs are: Tysa BG Division, Salovka BGIS, Palas Komarivtsi bgis, Uzhhorod BGD. A minatory period is favorable weather conditions during the year.

Since November 2016 due to the $100 \%$ readmission of detained irregular migrants by EU countries, the activity of irregular migrants has significantly decreased since the end of Q1 2017. If such a migration policy is continued in 2020, less active channels of irregular migration should be expected, which will be discredited by themselves. At the same time, there will be unorganized attempts at illegal border crossings or organized attempts to move of small groups of 3-8 irregular migrants.

The policy of the EU, Turkey and the Russian Federation in relation to refugees will influence on the flow of migrants, the tactics of OSGs' actions 
to move irregular migrants. In case of a certain overlap of irregular migrants channels in the South of EU, it is possible to make refocusing of the channels through the territory of Russia and Ukraine with the subsequent entry of some irregular immigrants from Russia to Ukraine via the CIS ERD section or transit through the Republic of Belarus (northern stream), transit by sea (southern stream). The reason will also not be the completion of the project 'Wall' on the Ukrainian and Russian borders with a total length of $1300 \mathrm{~km}$, the completion of which is possible by the end of 2020, but the deadlines are not concrete.

This stream of irregular migrants entered to the EU using the status of refugee, may be citizens of the Russian Federation. Also, these citizens can be involved to IAGs in Donetsk and Luhansk regions.

Accordingly, the probability of activity of illegal migration to Ukraine with the further penetration in the EU countries will be relevant.

at the Ukrainian and Polish section may be attempts to smuggle irregular migrants at the junction of the Verkhovyna Bystra and the Velykyi Bereznyi BG Divisions of the Border Guard Service;

use of the bgd sectors for the transit movement of irregular migrants originating from Africa, South east Asia to the Ukrainian and Slovakian border section;

violation of the state border regime by the citizens of Ukraine and Poland during the tourist season and the season of collecting wild berries.

in the Ukrainian and Slovakian section is the continuation of attempts by organized illegal groups to cross irregular migrants across the border to the Slovak Republic, mainly from Vietnam, Afghanistan, India, Bangladesh and Syria in the Velykyi Bereznyi region.

According to the reduced analysis, it is proposed to carry out the following measures to minimize threats and risks in the area of the Chop Border Guard Detachment:

1. Organization of detailed interaction with law enforcement agencies, OSD units on specific threats. Exchange of information on the tactics of the offenders, the number of persons, vehicles involved to a specific type of illegal activity. Elaboration of joint interaction plans and administrative documents with a distinction between powers and procedures.

2. Improving the exchange of information with a adjacent Country about a possible offense (not only criminal) both at checkpoints and outside them, with the possibility of providing supporting documents, photo and video materials. Conducting joint investigations, especially with regard to the accomplices of the offense.

3. Carrying out comprehensive measures in cooperation with other law enforcement agencies on combating corruption and involving staff in unlawful activities. Provide a systematic approach is motivating the staff for positive results of service, including the local border guard population. 
4. Permanent collection of pre-emptive information about a possible offense at a border or at a checkpoint,

5. Updating of databases, risk profiles and prompt bringing of changes in the situation to the border patrols and reserves.

6. Strengthen work on the selection of candidates for military service under contract.

7. Creating the right conditions to serve at the state border: limiting staff rotations, optimizing workloads, maintaining unit communications in workforce, utilizing specialty staff, improving nutrition, provisioning according to climatic conditions, etc.

8. Extension of the engineering and technical component of border guard protection, firstly the arrangement (restoration) of a fence, purchase of thermal and signaling equipment of a new sample.

\section{CONCLUSIONS}

During the analysis it was found that irregular migration is the crossing of state borders for the purpose or in a manner that violates its legislation, including international ones. All OSG processes outside the checkpoints have a previously unpredictable (random) nature. The parameters of the conditions in the area of responsibility of the Chop Border Detachment have both deterministic and uncertain character. Therefore, the effectiveness assessment model and partial performance indicators of counteracting irregular migration should be probabilistic. The methodology should solve the scientific problem of the rational distribution of forces and means of the Chop Border Detachment, taking into account the conditions of performance of tasks in specific territories of the entire area of responsibility.

\section{SUMMARY}

For the purpose of qualitative fulfillment of tasks, which are legally prescribed to the State Border Guard Service of Ukraine, the border units, within their competence, should adequately respond to the threats that appear in the area of border activity. The scientific article deals with the specifics of service operational activities implementation at the sector of Chop Border Detachment responsibility. The statistics analysis on illegal migration counteracting at green border was conducted and the specific tactics of border violators' actions were revealed. The conclusion on the necessity of finding ways to improve the efficiency of illegal migration counteracting organization at green border and the limited capacity of the available scientific and methodological apparatus for the rational distribution of border units' means and forces, taking into account the specific sector of Chop Border Detachment responsibility is presented in the article.

The author concludes that the parameters of the situation conditions at the sector of Chop Border Detachment responsibility are both deterministic 
and undefined. Therefore, the efficiency evaluation model and partial efficiency indicators should be probabilistic.

\section{REFERENCES}

1. Tematychnyy analiz ryzykiv: vyznachennya zahroz ta ryzykiv na dilyantsi zahonu $\mathrm{z}$ metoyu vyznachennya zavdan' pidporyadkovanym pidrozdilam na okhoronu derzhavnoho kordonu v 2019 rotsi (2018) [Thematic Risk Analysis: Identifying Threats and Risks at the Detachment Area to Identify Tasks for Subordinate Border Protection Units in 2019]. Chop, p. 26. (in Ukraine)

2. Stratehiya intehrovanoho upravlinnya kordonamy na period do 2025 roku [Elektronuj resurs] Rozporyadzhennya Kabinetu Ministriv Ukrayinu vid 24 lypnya 2019 roku № 687-r. Rezhum dostupu: https://zakon.rada.gov.ua/laws/show/687-2019-\%D1\%80 (data zvernennya: 30.12.2019) [An integrated border management strategy for the period up to 2025: [Electronic Resource] Order of the Cabinet of Ministers of Ukraine No. 687-r as of July 24, 2019, available at: https://zakon.rada.gov.ua/ laws/show/687-2019-\%D1\%80].

3. Pro Rishennya Rady natsionalnoyi bezpeky i oborony vid 06 travnya 2015 r. «Pro Stratehiyu natsionalnoyi bezpeky Ukrayiny». Ukaz Prezydenta Ukrayiny vid 06 travnya 2015 r. №287/2015. [Elektronuy resurs] - Rezhy`m dostupu: http://zakon3.rada.gov.ua/laws/show/n0008525-15 [On the Decision of the National Security and Defense Council as of May 06, 2015 « About the National Security Strategy of Ukraine» Decree of the President of Ukraine as of May 06, 2015, available at: http://zakon3.rada.gov.ua/laws/ show/n0008525-15.

4. Zakon Ukrayiny № 661-IV «Pro derzhavnu prukordonnu sluzhbu Ukrayinu» vid 3 kvitnya 2003 roku (Vidomosti Verxovnoyi Radu Ukrayinu, 2003, N 27, st. 2, 20). [Law No. 661-IV of Ukraine On the State Border Service of Ukraine as of April 3, 2003 (The Official Bulletin of the Verkhovna Rada of Ukraine (OBVR)), 2003, 27, Art. 208)]. [in Ukrainian]

5. Mejko O. V. (2014) Metoduka vuznachennya racionalnogo varianta zastosuvannya mobilnux grup okremogo viddilu prukordonnoyi sluzhbu tupy "S" pid chas uskladnennya obstanovku na dilyankax derzhavnogo kordonu [Methods of determining the rational variant of the use of Type C mobile teams of a separate department of the border service during the aggravation of the situation at the state border sections] Zbirnyk naukovykh prats, Kharkiv : KNAFU, No. 4 (41), pp. 153-156. [in Ukrainian]

6. Farion O. B. (2009) Metoduka ocinku efektuvnosti sustemu informacijnogo zabezpechennya viddilu prukordonnoyi sluzhbu tupy «B» [Methods of evaluation of the effectiveness of the system of information support of the Type B department of the border service] Zbirnyk naukovykh prats Natsionalnoi akademii Derzhavnoi prykordonnoi sluzhby Ukrainy im. 
B. Khmelnytskoho, Khmelnytskyi : NASBSU, no. 49, pp. 97-115. [in Ukrainian]

7. Kovalev D. V. (2017) Algorutm metoduku vuznachennya racionalnogo varianta organizaciyi operatuvno-sluzhbovoyi diyalnosti viddiliv prukordonnoyi sluzhbu tupy "A" $\mathrm{v}$ kontrolnux punktax vyizdu/vyjizdu [Algorithm of methodology of determination of rational variant of organization of operatively-official activity of departments of frontier service as "A» in the markpoints of entrance/of departure]. Zbirnyk naukovykh prats Natsionalnoi akademii Derzhavnoi prykordonnoi sluzhby Ukrainy im. B. Khmelnytskoho, Khmelnytskyi : NASBSU, no. 2(72), pp. 116-125. [in Ukrainian]

8. Shinkaruk O. M., Mosov S. P., Kirilenko V. A. (2018) Prykordonna bezpeka Ukrayiny: stanovlennya, suchasnyy stan, problemy i perspektyvy: monohrafiya [Border security of Ukraine: formation, current state, problems and prospects: monograph]. Khmelnytsky : NASBSU, p. 187 p. [in Ukrainian]

9. Blazhivsky E. M. (2008) International migration is one of the biggest problems of modern Ukraine. Visn. prokuratu, no. 6. pp. 3-13. [in English]

10. Rashitov L. R. (2016) Criminological characteristics of crimes in the sphere of illegal migration and their prevention. BULLETIN of the Kazan law Institute of the Ministry of internal Affairs of Russia, no. 1(23), pp. 124-28. (in English)

11. Malinovska O. A. (2018) Migration policy: global context and Ukrainian realities: monograph. Kiev : NISD, 472 p. (in English)

12. Purygina O. G. (2007) International migration: studies. stipend. Kiev : VC «Academy», 312 p. (in English)

13. Babiia V. M., Koretsky V. M. (1974) Law dictionary / edited by academics of VSSR Academy of Sciences. Kiev, 844 p. (in English)

14. Gusarov S. M., Komzuk A. T., Salmanova A. Yu. (2016) Migration law of Ukraine : textbook. Kharkiv : advertising House, 296 p. (in English)

15. Kuzmenko O. V. (2000) Administrative and legal counteraction to illegal migration in Ukraine: dis. ... Cand. Law. Sciences. Kiev, 196 p. (in Ukrainian)

16. Mosiondz S. O. (2005) Administrative and legal bases of the state migration policy in Ukraine. Kiev : Master of the twenty-first century, $206 \mathrm{p}$. (in Ukrainian)

17. On the legal status of foreigners and stateless persons. Law of Ukraine No. 3773-VI of September 22, 2011 (Vidomosti Verkhovnoi Rady Ukrainy (VVR), 2012, No. 19-20, art. 179) . Retrieved from: https://zakon.rada.gov.ua/laws/show/3773-17. (in Ukrainian)

18. Binkovskyi O. A., Zalozh V. V., Dovgan V. I. (2016) Mechanisms for countering irregular migration in Ukraine. Eurasian Academic Research Journal, no. 2(02), pp. 14-22. (in English)

19. Shevchenko O. M. (2010) Udoskonalennja mekhanizmiv derzhavnogho upravlinnja mighracijnymy procesamy [Improving the 
mechanisms of state management of migration processes]. Donetsk. 2010. 25 p. (in Ukrainian)

20. Zakharchenko M. (2014) Prychyny ta sutnistj javyshha nereghuljarnoji (neleghaljnoji) mighraciji [Reasons and essence of the phenomenon of irregular (illegal) migration]. Customs activity, pp. 262-267. (in Ukrainian)

21. Mozol A. P. (2002) Kryminologhichni problemy neleghaljnoji mighraciji $\mathrm{v}$ Ukrajini [Criminological problems of illegal migration in Ukraine]. Kiev, 212 p. (in Ukrainian)

22. Ognev T. E. (2017) Nereghuljarna mighracija: kryminaljne pravo ta kryminologhichni aspekty [Irregular migration: criminal law and criminological aspects]. Institute of state and law. V. M. Koretsky, 20 p. (in Ukrainian)

23. Kapitanchuk L. Yu. (2009) Okremi pytannja rozsliduvannja porushenj derzhavnogho kordonu Ukrajiny za uchastju neleghaljnykh mighrantiv [Separate issues of investigation of violations of the state border of Ukraine with the participation of illegal migrants]. Universytetsjki naukovi zapysky, no. 1. pp. 306-312. (in Ukrainian)

24. Kapitanchuk L. Yu. (2008) Sposib vchynennja zlochynu ta jogho osoblyvosti pry nezakonnomu perepravlenni osib cherez derzhavnyj kordon Ukrajiny [Sposib vchynennja zlochynu ta jogho osoblyvosti pry nezakonnomu perepravlenni osib cherez derzhavnyj kordon Ukrajiny]. Forum prava, no. 2, pp. 210-219. (in Ukrainian)

25. Kapitanchuk L. Yu., Litvin Yu. I. (2015) Vplyv zminy potokiv neleghaljnoji mighraciji na formuvannja kryminalistychnoji kharakterystyky nezakonnogho perepravlennja osib cherez derzhavnyj kordon Ukrajiny [Influence of Changes in Illegal Migration Flows on Formation of Forensic Characteristics of Illegal Trafficking of Persons across the State Border of Ukraine]. Dosudove rozsliduvannja : aktualjni problemy ta shljakhy jikh vyrishennja : materialy postijno dijuchogho nauk. - prakt. seminaru. Pravo, no. 7. pp. 344. (in Ukrainian)

\section{Information about the author: Volodymyr Kyrylenko,}

Doctor of Technical Sciences, professor, chief research fellow,

Bohdan Khmelnytskyi National Academy of the State Border Guard Service of Ukraine 46 Shevchenka str., Khmelnitskyi, 29007, Ukraine

ORCID ID: orcid.org/0000-0002-2206-1651 